\title{
Molecular Detection of Ampicillin Resistant Genes in E. coli Isolates from Dogs in India
}

\author{
${ }^{1,2 *}$ Mustapha, M., ${ }^{1}$ Goel, P. and ${ }^{1}$ Jain, V. K. \\ ${ }^{1}$ Department of Veterinary Medicine, Lala Lajpat Rai University of Veterinary and Animal Sciences, Hisar, Haryana, India \\ ${ }^{2}$ Department of Veterinary Medicine, University of Maiduguri, Borno State, Nigeria
}

*Author for Correspondence: tanimuzimbos@gmail.com

\begin{abstract}
The most common cause of urinary tract infection in dogs is uropathogenic Escherichia coli (UPEC). This condition often presents with vaginal discharge, dribbling of urine, straining or vocalization while urinating due to pain. Furthermore, the following signs are also noticeable: hematuria, lethargy, proteinuria, dysuria, cystitis, and oliguria. The aim of this research was to investigate the genes of ampicillin resistance in $E$. coli isolates from dogs with urinary tract infections. Out of 103 urine samples cultured (Blood agar, MacConkey's lactose agar and Eosin methylene blue agar), 24.3\% were positive for uropathogenic Escherichia coli. The positive isolates were further subjected to antimicrobial sensitivity test and PCR analysis. All the uropathogenic Escherichia coli isolates were resistant to ampicillin while 96\% were resistant to Cloxacillin and Oxytetracycline. Susceptibility to Meropenem, Gentamicin and Amikacin were $64 \%, 44 \%$ and $40 \%$ respectively. All the 25 strains of the E. coli were identified to be resistant to two or more antibiotics. The PCR result showed the presence of bla $a_{A M P C}$ in all the samples and $60 \%$ had bla $_{T E M}$ genes responsible for ampicillin resistance. However, none of the isolates were positive for the $b l a_{S H V}$ gene. The presence of the bla $\mathrm{AMPC}_{\mathrm{AM}}$ and bla $\mathrm{T}_{\mathrm{TEM}}$ genes in the dogs studied resulted in ampicillin resistance, with bla commonly detected ampicillin gene in Escherichia coli in the study area. Meropenem was also found to be a good choice for treating uropathogenic E. coli infection in dogs.
\end{abstract}

Keywords: Ampicillin resistance genes; Escherichia coli; Dogs; PCR; Uropathogenic

\section{INTRODUCTION}

Escherichia coli (E. coli) is considered one of the major causes of human and dog infections. It is also a common human and animal inhabitant (Sørum and Sunde, 2001), and an indication of water and food fecal contamination. Pathogenic variants cause bowel and extra-intestinal infections, including gastroenteritis, inflammation of the urinary tract, meningitis, peritonitis and septicaemia (Van Baum and Marre, 2005; Sodha et al., 2011). The widespread use of antibiotics may be associated with the development of antibiotic resistance in pathogenic and non-pathogenic $E$. coli strains (Sunde and Sorum, 1999). Antibiotic resistance is highly prevalent worldwide in bacterial isolates, especially in developing countries (Calva et al., 1996; Hoge et al., 1998). The spread of resistance genes through the transfer of plasmids plays an important role in the spread of resistance genes in Gram-negative enteric pathogens (Saw et al., 2007). Routine antibiotic resistance monitoring tends to help provide information on antibiotic therapy and the control of resistance (Johnson, 2015). Normal intestinal flora is a reservoir of resistance genes in commensal $E$. coli which has been reported to be a useful indicator of antibiotic resistance in the population of bacteria (Levy, 1997). Multi-resistant Escherichia coli has previously been reported in humans and various animal species, especially in dogs and cats (Saenz, et al., 2004). On the other hand, Enterobacteriaceae's production of extended-spectrum beta-lactamases (ESBLs), particularly by $E$. coli, has been a significant cause of concern in several countries, frequently causing human and dog infections (Poeta et al., 2005; Pinto et al., 2010; Seni et al., 2016).

Escherichia coli related research is particularly relevant because they can be found in several niches, including hosts of humans and animals (O'Brien, 1997). However, E. coli strains can share genetic material effectively with other pathogenic organisms such as Salmonella, Shigella, Yersinia and Vibrio, as well as with pathogenic E. coli (Johnson et al., 2007). Antimicrobial resistance to $\beta$-lactam in $E$. coli is mediated primarily by $\beta$-lactamases, hydrolysis of the $\beta$ lactam ring and inactivating antibiotics (Livermore, 1995). Several different $\beta$-lactamases were described and more than $200 \beta$-lactamases were classified into four main groups and eight subgroups by function and structural characteristics (Bush et al., 1995; Bush and Jacoby, 1997). TEM, SHV and 
$O X A$, including $A M P C \beta$-lactamases, have been reported to be the most prevalent (Bradford, 2001). Antimicrobial agents such

as, trimethoprim-potentiated sulphonamides and cephalexin we re reported to be effective against $E$ coli UTI (Seguin et al., 2003; Pedersen et al., 2007; Ball et al., 2008). However, there are concerns about increased antimicrobial resistance to fluoroquinolones in dogs with UTI among $E$. coli isolates (Gibson et al., 2008). Unfortunately, there is limited information on the antimicrobial resistance of ampicillin among companion animals in India despite evidence of the transfer of resistance between animals and their owners. Therefore, the objective of this study was to investigate the ampicillin resistance genes in E. coli infections among dogs presented with UTI at the small animal section of Veterinary Clinical Complex (VCC), Lala Lajpat Rai University of Veterinary and Animal Sciences (LUVAS) Hisar Haryana.

\section{MATERIALS AND METHOD}

\section{Sample Collection}

A total of 103 urine samples were collected aseptically through cystocentesis from non-medicated adult dogs of both sexes and of different breeds with a presumptive diagnosis of UTIs in the small animal section of Veterinary Clinical Complex (VCC), Lala Lajpat Rai University of Veterinary and Animal Sciences (LUVAS) Hisar Haryana, India for a period of one year (January 2017 to February 2018).

\section{Bacteriological Examination}

The fresh urine samples collected aseptically were inoculated and streaked onto a 5\% sheep blood agar (BA) (HiMedia, Mumbai, India) and MacConkey's lactose agar (MLA) (HiMedia, Mumbai, India) plates separately. The plates were incubated aerobically at $37^{\circ} \mathrm{C}$ for $24-48$ hours till adequate growth was observed. Suspected colonies were streaked onto Eosin Methylene Blue agar (EMB) (HiMedia, Mumbai, India), and incubated aerobically at $37^{\circ} \mathrm{C}$ for 24 hours. The appearance of blue-green colonies with a greenish metallic sheen on EMB was presumptively considered as indicating Escherichia coli.

Gram staining of the positive samples were performed to identify Escherichia coli by their Gram reaction. Positive isolates were chosen for biochemical testing based on colony appearance. (Indole, Methyl Red, Voges Proskauer, Citrates tests, Glucuronidase, Nitrate reduction, ONPG, Lysine utilization, Lactose, Glucose, Sucrose and Sorbitol) using commercially available KB010 Hi E. coli ${ }^{T M}$ Identification Kit (HiMedia Mumbai, India) following the manufacturer's instructions.

\section{Antimicrobial Susceptibility Testing}

The Antimicrobial susceptibility testing was performed acco rding to the method of Bauer-Kirby (Bauer et al., 1966) by using commercially prepared discs (Himedia, India) with known concentrations of antibiotics.

The antibiotics tested were ampicillin (AMP) $10 \mathrm{mcg}$, amoxi clav (AMC) $30 \mathrm{mcg}$, amikacin (AK) $30 \mathrm{mcg}$, ceftizoxime (CZX) 30cmg, gentamycin (GEN), 30mcg, meropenem
(MRP) 10mcg, Cloxacillin (COX) 1mcg, and Oxytetracycline (O) 30mcg (HiMedi, Mumbai, India). A zone of inhibition was measured and interpreted as sensitive $(\mathrm{S})$, intermediate $(\mathrm{I})$, and resistant (R) according to the interpretation chart provided by the manufacturer. Resistances involving three or more classes of antibiotics were defined as multi-drug resistance (MDR).

\section{Extraction of Genomic DNA}

DNA of Escherichia coli from all the positive isolates was extracted using commercially available PureLink ${ }^{\mathrm{TM}}$ Genomic DNA mini kit (Invitrogen, USA) following the manufacturer's instructions. The extracted DNA was kept at $-20^{\circ} \mathrm{C}$ until further use.

\section{Detection of Ampicillin resistance gene}

The presence of Ampicillin resistance genes in E. coli DNA extracts was determined by conventional PCR. Primers sequences, target genes, products size and references are given in table 1 . The conventional PCR was performed in veriti thermocycler (ABI, USA) in 25 volume reaction containing $6 \mu \mathrm{l}$ of template DNA, $1 \mu 1$ of each of the primers (10pmoles concentration), $12.5 \mu$ l Phusion PCR Master-mix (2X) (High Fidelity, USA), $1 \mu \mathrm{l}$ DMSO and $2.5 \mu$ l of nuclease free water. Amplification procedure consisted of initial denaturation at $98^{\circ} \mathrm{C}$ for $30 \mathrm{sec}$, followed by 35 cycles of denaturation at $98^{\circ} \mathrm{C}$ for $10 \mathrm{sec}$, annealing at $60^{\circ} \mathrm{C}$ for $30 \mathrm{sec}$, extension at $72^{\circ} \mathrm{C}$ for $30 \mathrm{sec}$ and final extension at $72^{\circ} \mathrm{C}$ for 5 min. The PCR products were analyzed on $1.5 \%$ agarose gel electrophoresis and visualized under UV trans-illuminator GEL DOCTM (BIO RAD, India) and documented by photography for further analyses.

\section{Ethical Approval}

The samples used in the current study were from clinical cases presented to the hospital. Thus, Lala Lajpat Rai University of Veterinary and Animal Sciences does not require Ethical approval for clinical cases.

\section{Data Analysis}

The data obtained from the study were analyzed using descriptive statistics with JMP Version 11 (SAS, Inc. NC, USA).

\section{Results}

Out of the 103 urine samples screened, 25 (24.3\%) were positive for uropathogenic Escherichia coli. The result of antimicrobial susceptibility test indicated that the isolates were resistant to Ampicillin 25 (100\%), Cloxacillin 24 (96.0\%), Oxytetracycline $24(96.0 \%)$, Ceftizoxime 19 (76.0\%), and Amoxyclav $12(48.0 \%)$ while they were susceptible to Meropenem 16 (64.0), Gentamycin 11 (44.0\%) and Amikacin $10(40.0 \%)$ as presented in Table 2.

Resistance has been described in three or more classes of antibiotics. And all of the 25 strains of $E$. coli have been identified as resistant to multi-drug as shown in Table 3. 
Table1. Primers used for PCR assays

\begin{tabular}{|c|c|c|c|}
\hline Target genes & Primer sequence & Product size (bp) & Reference \\
\hline bla $_{T E M}$ & $\begin{array}{l}\text { Tem-F:TTCTTGAAGACGAAAGGGC } \\
\text { Tem-R:ACGCTCAGTGGAACGAAAAC }\end{array}$ & 1150 & (Brinas et al., 2005) \\
\hline$b l a_{S H V}$ & $\begin{array}{l}\text { shv-F:CACTCAAGGATGTATTGTG } \\
\text { shv-R:TTAGCGTTGCCAGTGCTCG }\end{array}$ & 885 & (Pitout et al., 1998) \\
\hline bla $_{A M P C}$ & $\begin{array}{l}\text { ampC-F:AATGGGTTTTCTACGGTCTG } \\
\text { ampC-F:AATGGGTTTTCTACGGTCTG }\end{array}$ & 191 & (Caroff et al., 1999) \\
\hline
\end{tabular}

Table 2: Antibiotic Susceptibility Pattern of E. coli isolates from dogs $(n=25)$

\begin{tabular}{llll}
\hline Antibiotics & $\begin{array}{l}\text { No. of resistant } \\
\text { isolates (\%) }\end{array}$ & $\begin{array}{l}\text { No. of intermediate } \\
\text { isolates (\%) }\end{array}$ & $\begin{array}{l}\text { No. of susceptible } \\
\text { isolates (\%) }\end{array}$ \\
\hline Amikacin & $9(36.0)$ & $6(24.0)$ & $10(40.0)$ \\
Amoxyclav & $12(48.0)$ & $3(12.0)$ & $10(40.0)$ \\
Ampicillin & $25(100)$ & $0(0.0)$ & $0(0.0)$ \\
Ceftizoxime & $19(76.0)$ & $0(0.0)$ & $6(24.0)$ \\
Cloxacillin & $24(96.0)$ & $0(0.0)$ & $1(4.0)$ \\
Gentamicin & $9(36.0)$ & $5(20.0)$ & $11(44.0)$ \\
Meropenem & $6(24.0)$ & $3(12.0)$ & $16(64.0)$ \\
Oxytetracycline & $24(96.0)$ & $0(0.0)$ & $1(4.0)$ \\
\hline
\end{tabular}

Table 3: Multi drug Resistance (MDR) Pattern of E. coli isolates from dogs

\begin{tabular}{ll}
\hline Number of isolates & No. of antibiotic found resistant \\
\hline 1 & 8(Amikacin, Amoxyclav, Ampicillin, Ceftizoxime, Cloxacillin, Gentamicin, Meropenem \\
& and Oxytetracycline) \\
2 & 4(Cloxacillin, Gentamicin, Meropenem and Oxytetracycline) \\
3 & 7(Amikacin, Amoxyclav, Ampicillin, Ceftizoxime. Cloxacillin, Gentamicin and \\
4 & Meropenem) \\
5 & 6(Ampicillin, Ceftizoxime, Cloxacillin, Gentamicin, Meropenem and Oxytetracycline) \\
7 & 3(Amoxyclav, Meropenem and Ceftizoxime) \\
& 5(Amikacin, Amoxyclav, Oxytetracycline, Cloxacillin and Ampicillin) \\
\hline
\end{tabular}

\section{Detection of Ampicillin Resistance Genes}

Polymerase Chain Reaction (PCR) with primers specific for the $b l a_{A M P C}, b l a_{T E M}$ and $b l a_{S H V}$ genes were performed for the 25 ampicillin resistance $E$. coli isolates and the results are shown in Table 4. bla $a_{A M P C}$ genes were found to be positive for all the E. coli isolates (Figure 1). bla TEM was detected by PCR line 2, 4-12 14, 16 and 21-23 of the isolates (Figure 2). The result for bla $a_{S H V}$ genes was negative for all isolates.

Table 4. Distribution of Ampicillin resistance genes among 25 E. coli isolates from dogs with UTI

\begin{tabular}{lll}
\hline Antimicrobial agents & Resistance genes & No. of positive isolates (\%) \\
\hline Ampicillin & $b \operatorname{la}_{A M P C}$ & $25(100)$ \\
& $b \operatorname{la}_{T E M}$ & $15(60.0)$ \\
& $b a_{S H V}$ & $0(0.0)$ \\
\hline
\end{tabular}




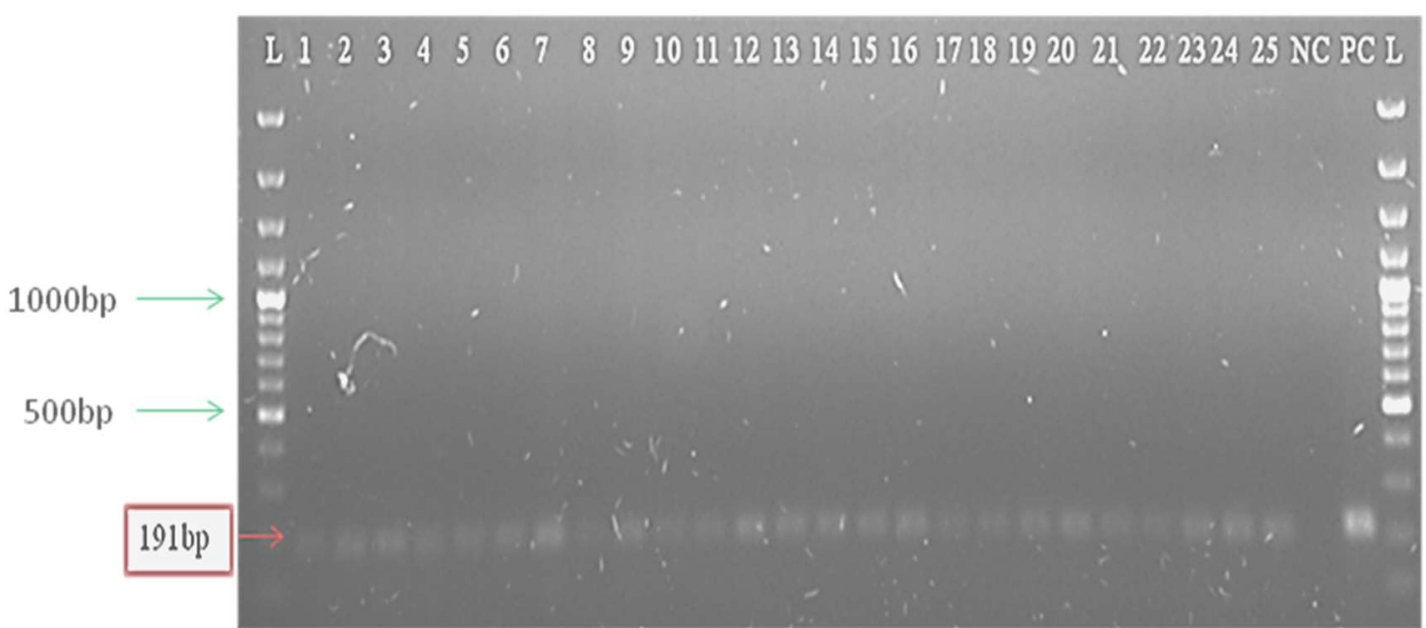

Figure. 1. Agarose gel electrophoresis showing PCR amplified products of ampicillin resistance gene (bla $\left.a_{A M P C}\right)$ of E. coli isolates

Lane L: 100 bp DNA ladder

Lane: $1-25$ positive samples (191bp)

Lane NC: negative control

Lane PC: positive control

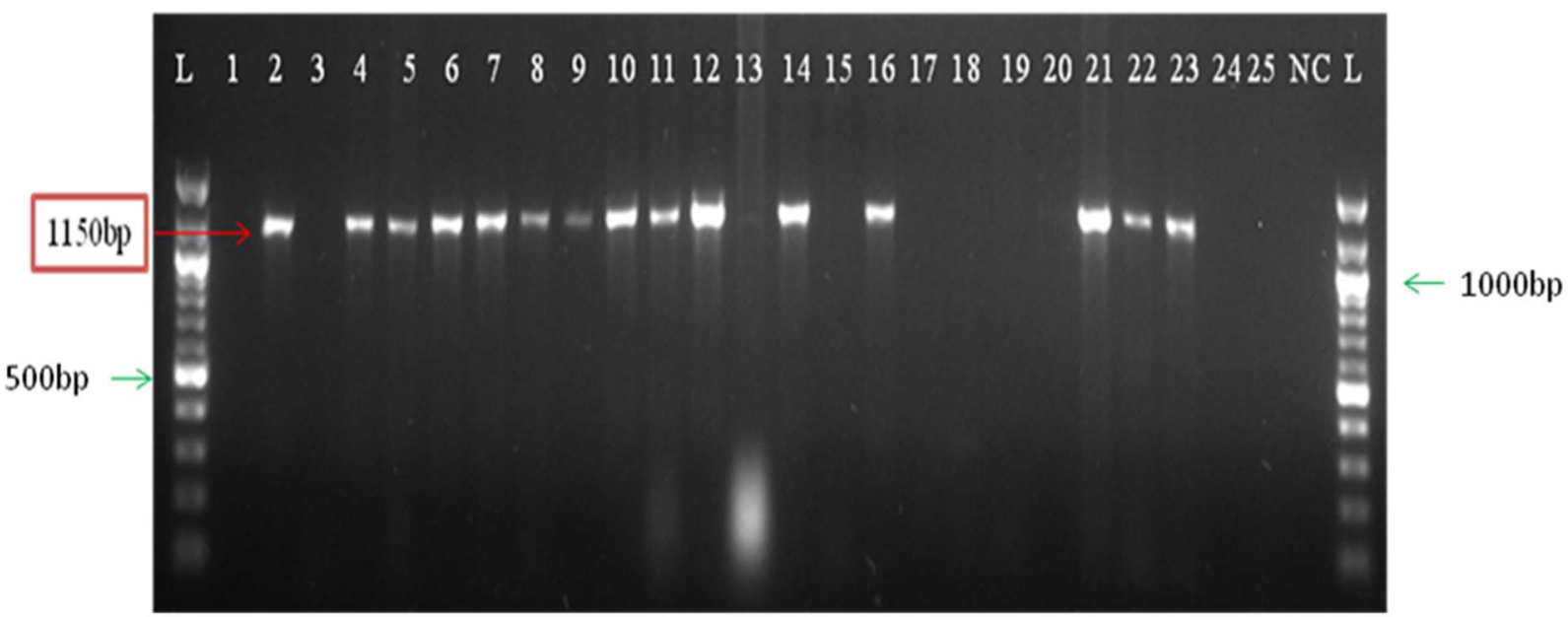

Figure. 2: Agarose gel electrophoresis showing PCR amplified product of ampicillin resistance gene (bla $\left.a_{T E M}\right)$ of E. coli isolates

Lane L: 100bp DNA ladder

Lane: 2, 4-12 14, 16 \&21-23 positive samples (1150bp)

Lane: 1, 3, 13, 15 \& 17-19 negative samples

Lane NC: negative control

\section{DISCUSSION}

The present study revealed that $24.3 \%$ of the dogs examined were positive for uropathogenic Escherichia coli. This result is lower than those reported from similar studies by Kuan et al. (2016), Moyaert et al. (2017) and Liu et al. (2017) who reported $35.6 \%, 46.7$ and $60.9 \%$, respectively. This report signified he occurrence of $E$. coli amongst dogs with urinary tract infections.

The antimicrobial susceptibility pattern of the Escherichia coli isolates to Beta lactams antibiotics documented in the current studies showed a significantly high level of resistance. This finding revealed that the extensive use of ampicillin and other Beta lactams antibiotics might be linked with the variety of antibiotics resistance mechanisms in pathogenic and non-pathogenic $E$. coli isolates, as narrated by Rubab and Oh (2021). From the present study, the high degree of antibiotic resistance among the $E$. coli isolates is attributed to the cases of urinary tract infections in dogs presented to the Veterinary Clinical Complex (VCC) hospital. This might be associated with the fact that VCC is a tertiary referral hospital where large numbers of sick dogs with various health complications are admitted, as previously observed by Mustapha et al. (2019). It is pertinent to note that antimicrobial-resistant $E$. coli in dogs represent a potential threat to veterinary and public health. Resistance to ampicillin which showed highest degree of resistant level in 
the current study was higher than those previously reported by Lei et al. (2010) from dogs, similarly, the findings of the present study buttressed the reports of Cavalho et al. (2016) and Liu et al. (2017) who have also recorded high level of ampicillin resistance in $E$. Coli.

The role played by domesticated animals, including dogs in diseases transmission to humans, has been well documented, principally through direct contact with infected animals (Cummings et al., 2012). Moreover, there are usually mutual connections between humans and pet animals in many parts of the world. Thus, direct contact with infected dogs may serve as a source of disease transmission of pathogen $E$. coli in humans (Simjee et al., 2002; Stockholm et al., 2012).

The E. coli isolates in the present study were found to be susceptible to meropenem, gentamicin and amikacin. Our finding unveiled that meropenem could be considered to be the drug of choice for the treatment of uropathogenic E. coli since it has shown the highest susceptibility. Furthermore, this compound is one of the recent drugs that can be used to combat infection due to extended Beta-lactamase producing Enterobacteriaceae (ESBLs) (Pitout and Laupland, 2008).

However, the efficacy of meropenem especially against $E$. coli isolated strains may be associated with its high cost, unpopular use and less availability for abuses amongst veterinarians. Better still, gentamicin and amikacin, which belongs to the same class of aminoglycoside, have also shown high efficacy in the treatment of uropathogenic $E$. coli. This may be related to the complexity of the aminoglycoside in pathogen-drug resistance pathways (Onanuga et al., 2005).

The findings of the present study have revealed that the 25 isolates of $E$. coli show different degrees of multi-drug resistance. This result concurs with the works of Kang et al. (2005) and Cummings et al. (2015). However, in contrast to the findings of the present study, a lower degree of multi-drug resistance E. coli isolates has been previously reported (Windahl et al., 2014; Tramuta et al., 2014).

The PCR analysis of the antibiotic resistance genes revealed the genes responsible for the resistance and the genes for conferring ampicillin resistance have been determined in all the canine uropathogenic $E$. coli isolates tested. The gene $b l a_{A M P C}$ and bla $_{T E M}$ were detected and have been previously described in E. coli isolates of animal origin (Brinas et al., 2005; Chang et al., 2015). The results of this study indicated that $b a_{A M P C}$ was the most common gene among the ampicillin resistance $E$. coli isolated in Hisar, which is in disagreement with the result of previous studies that reported

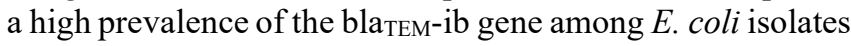
(Brinas et al., 2005; Vo et al., 2007). In addition, bla TEM $_{\text {was }}$ found in 15 ampicillin resistance isolates. These findings supported the results of Brinas et al. (2002), who reported 103 bla $_{T E M}$ genes in resistance E. coli isolates from food and healthy animals. The third gene $b l a_{S H V}$, whose presence was assayed, was not found in any isolates. Thus, this might indicate the presence of $b l a_{A M P C}$, and $b l a_{T E M}$ ampicillinresistance gene in canine uropathogenic $E$. coli isolates in Hisar. However, a previous study by Brinas et al. (2002) had reported that none of the $E$. coli isolates showed a positive reaction to bla $a_{S H V}$. Moreover, this finding provides evidence of the widespread distribution of bla $a_{A M P C}$ and bla $a_{T E M}$ in uropathogenic canine E. coli isolates here in Hisar, and therefore using Beta-lactams antimicrobial agent in the treatment of canine infections may lead to more emergence of resistant $E$. coli and other bacterial isolates.

\section{Conclusion}

In conclusion ampicillin resistance in the dogs studied was due to the presence of bla $_{A M P C}$ and bla $\mathrm{a}_{T E M}$ gene, with bla $\mathrm{a}_{\mathrm{A} P C}$ as the most commonly encountered ampicillin gene in Escherichia coli in the study area. It was also concluded that meropenem could be considered as a drug of choice for the treatment of uropathogenic $E$. coli infection in dogs.

\section{Conflict of Interest}

The authors declare that they have no conflict of interest.

\section{Authors Contribution}

The study was conceived and designed by MM and PG. MM carried out the study, analyzed the data, and wrote the manuscript. The study was overseen by VKJ. The final manuscript was read and approved by all authors

\section{Acknowledgements}

This work was financed by the Indian Council for Cultural Relations (Ministry of External Affairs, Government of India) and Department Veterinary Medicine, LUVAS, Hisar, Haryana.

\section{REFERENCES}

Ball, K.R., Rubin, J.E., Chirino-Trejo M. and Dowling, P.M. (2008). Antimicrobial resistance and prevalence of canine uropathogens at the Western College of Veterinary Medicine Veterinary Teaching Hospital, 2002-2007. Canadian Veterinary Journal. 49,985990. PMID: 19119366

Bauer, A.W., Kirby, W.M.M, Sherris, J.C. and Turck, M. (1966). Antibiotic susceptibility testing by standardized single disk method. American. Journal of Clinical Patholog, 45,493-496. PMID: 5325707

Bradford, P.A. (2001). Extended-spectrum $\beta$-lactamases in the 21st century: characterization, epidemiology, and detection of this important resistance threat. Clinical Microbiology Reviews, 14, 933-951. DOI: 10.1128/CMR.14.4

Brinas, L., Lanteo, M., DeDiego, I., Alvarez. M., Zarazag, M. and Torres. C. (2005). Mechanisms of resistance to expanded spectrum cephalosporins in E. coli isolates recovered in a Spanish hospital Journal of Antimicrobial Chemotherapy, 56, 1107-1110. DOI: 10.1093/jac/dki370

Brinas, L., Zarazaga, M., Saenz, Y., Ruiz-Larrea, F. and Torres. C. (2002). Beta-lactamases in ampicillinresistant Escherichia coli isolates from foods, humans and healthy animals. Antimicrobial Agent and Chemotherapy, 46, 3156-3163. DOI: 10.1128/ aac.39.6.1211.

Bush, K. and Jacoby, G.A. (1997). Nomenclature of TEM $\beta$-lactamases. Journal Antimicrobial and Chemothe rapy. $39: 13$ 
Bush, K., Jacoby, G.A. and Medeiros, A.A (1995). A functional classification scheme for beta-lactamases and its correlation with molecular structure. Antimicrobial Agents Chemotherapy. 39,12111233. DOI: $10.1128 /$ aac.39.6.1211

Calva, J.J., Sifuentes-Osornio, J. and Céron, C. (1996). Antimicrobial resistance in fecal flora: longitudinal community-based surveillance of children from urban Mexico. Antimicrobial Agents Chemotherapy. 40, 1699-1702. DOI: 10.1128/AAC.40.7.1699

Caroff, N., Espaze, E., Berard, I., Richet, H. and Reynaud, A. (1999). Mutations in the ampC promoter of Escherichia coli isolates resistant to oxyiminocephalosporins without extended spectrum $\beta$-lactamase production. FEMS Microbiology letters 173,459-465. DOI: 10.1111/j. 1574-6968.1999.tb13539.x

Carvalho, A.C., Barbosa, A.V., Arais, L.R., Ribeiro, P.F., Carneiro, V.C. and Cerqueira, A.M.F. (2016). Resistance patterns, ESBL genes, and genetic relatedness of Escherichia coli from dogs and owners. Brazilian Journal Microbiology. 47,150158. DOI.org/10.1016/j.bjm.11.005

Chang, S.K., Lo, D.Y., Wei, H.W. and Kuo, H.C. (2015). Antimicrobial resistance of Escherichia coli isolates from canine urinary tract infections. Journal of Veterinary and Medical Sciences, 77, 59-65. DOI: 10.1292/jvms. 13-0281

Cummings, K.J., Aprea, V.A. and Altier, C. (2015). Antimicrobial resistance trends among canine Escherichia coli isolates obtained from clinical samples in the northeastern USA, 2004-2011. Canadian Veterinary Journal, 56,393-398. PMCID: PMC4357913

Cummings, K.J., Warnick, L.D., Davis, M.A., Eckmann, K, Gröhn, Y.T., Hoelzer, K., MacDonald, K., Root, T.P., Siler, J.D., McGuir,e S.M. and Wiedmann, M. (2012). Farm animal contact as risk factor for transmission of bovine-associated Salmonella subtypes. Emerging Infectious Diseases.18, 19291936. DOI: $10.3201 /$ eid1812.110831

Gibson, J.S., Morton, J.M., Cobbold, R.N., Sidjabat, H.E., Filippich, L.J. and Trott, D.J. (2008). Multidrugresistant E. coli and Enterobacter extraintestinal infection in 37 dogs. Journal of Veterinary Internal Medicine, 22, 844-850. DOI: 10.1111/j.19391676.00124.x

Hoge, C.W., Gambel, J.M., Srijan, A., Pitarangsi, C. and Echeverria, P. (1998). Trends in antibiotic resistance among diarrheal pathogens isolated in Thailand over 15 years. Clinical Infectious Disease, 26, 341-345. DOI: 10.1086/516303

Johnson, A. P. (2015). Surveillance of antibiotic resistance. Philosophical Transactions of the Royal Society B: Biological Sciences, 370(1670), 20140080. DOI: 10.1098/rstb.0080

Johnson, T.J., Kariyawasam, S., Wannemuehler, Y., Mangiamele, P., Johnson, S.J., Doetkott, C., Skyberg, J.A., Lynne, A.M., Johnson, J.R. and Nolan, L.K. (2007). The genome sequence of avian pathogenic Escherichia coli strain O1: K1: H7 shares strong similarities with human extraintestinal pathogenic E. coli genomes. Journal of Bacteriology.189, 3228-3236. DOI: 10.1128/JB.01726-06

Kang, S., Lee, D., Shin, S., Ahn, J. and Yoo. H. (2005). Changes in patterns of antimicrobial susceptibility and class 1 integron carriage among Escherichia coli isolates. Journal of Veterinary Sciences, 6,201205. PMID: 16131822

Kuan, N.L., Chang, C.W., Lee, C.A. and Yeh, K.S. (2016). Extended-Spectrum Beta-Lactamase-Producing Escherichia coli And Klebsiella pneumoniae Isolates from the Urine of Dogs and Cats Suspected of Urinary Tract Infection in a Veterinary Teaching Hospital. Taiwan Veterinary Journal, 42, 143-148. DOI.org/10.1142/S1682648515500274

Lei, T., Tian, W., He, L., Huang, X.H., Sun, Y.X., Deng, Y.T., Sun, Y., Lv, D.H., Wu, C.M., Huang, L.Z. and Shen, J.Z. (2010). Antimicrobial resistance in Escherichia coli isolates from food animals, animal food products and companion animals in China. Veterinary Microbiology, 146, 85-89. DOI: 10.1016/j.vetmic.2010.04.025

Levy, S.B. (1997). January. Antibiotic resistance: an ecological imbalance. In Ciba Found Symposium 207, 1-9. DOI: 10.1002/9780470515358.ch1

Liu, X., Liu, H., Li, Y. and Hao, C. (2017). Association between virulence profile and fluoroquinolone resistance in Escherichia coli isolated from dogs and cats in China. Journal of Infection in Developing. Countries. 11,306-313. DOI: 10.3855/jidc.8583

Livermore, D.M. (1995). beta-Lactamases in laboratory and clinical resistance. Clinical Microbiology Reviews, 8, 557-584. DOI: 10.1128/CMR.8.4.557

M., Chakraborty, T. and Mshana, S.E. (2016). Multiple ESBL-producing Escherichia coli sequence types carrying quinolone and aminoglycoside resistance genes circulating in companion and domestic farm animals in Mwanza, Tanzania, harbor commonly occurring plasmids. Frontiers in Microbiology 7,142. DOI: $10.3389 /$ fmicb.2016.00142

Moyaert, H., Morrissey, I., de Jong, A., El Garch, F., Klein, U., Ludwig, C., Thiry, J. and Youala, M. (2017). Antimicrobial susceptibility monitoring of bacterial pathogens isolated from urinary tract infections in dogs and cats across Europe: ComPath results. Microbial Drug Resistance, 23,391-403. DOI: 10.1089/mdr.2016.0110

Muhammad, M., Parveen, G., Vinay, K., Divya, A., Tarun, K. and Sushila, M. (2019). Isolation of uropathogenic Escherichia coli from dogs and molecular detection of chloramphenicol resistance genes. Haryana Veterinarian 58, 66-69.

O'Brien O'Brien, T.F. (1997). The global epidemic nature of antimicrobial resistance and the need to monitor and manage it locally. Clinical Infectious Disease, 24, S2-S8. DOI: 10.1093/clinids/24.supplement 1.s2

Onanuga, A., Oyi, A.R. and Onaolapo, J.A. (2005). Prevalence and susceptibility pattern of methicillin resistant Staphylococcus aureus isolates among 
healthy women in Zaria, Nigeria. African Journal of Biotechnology 4, 1321-1324. DOI: 10.1093/jac/dk $\mathrm{m} 269$

Pedersen, K., Pedersen, K., Jensen, H., Finster, K., Jensen, V.F. and Heuer, O.E. (2007). Occurrence of antimicrobial resistance in bacteria from diagnostic samples from dogs. Journal of Antimicrobial Chemotherapy, 60,775-781. DOI: $10.1093 / \mathrm{jac} / \mathrm{dkm}$ 269

Pinto, L., Radhouani, H., Coelho, C., da Costa, P.M., Simões, R., Brandão, R.M., Torres, C., Igrejas, G. and Poeta, P. (2010). Genetic detection of extended-spectrum $\beta$-lactamase-containing Escherichia coli isolates from birds of prey from Serra da Estrela natural reserve in Portugal. Applied and Environmental Microbiology, 76, 4118-4120. DOI: 10.1128/AEM.02761-09

Pitout, J.D. and Laupland, K.B. (2008). Extended-spectrum $\beta$-lactamase-producing Enterobacteriaceae: an emerging public-health concern. Lancet Infectious Disease. 8,159-166. DOI: 10.1016/S14733099(08)70041-0

Pitout, J. D. D., Thomson, K.S., Hanson, N.D., Ehrhardt, A.F., Moland, E.S. and Sanders, C.C. (1998). $\beta$ Lactamases responsible for resistance to expandedspectrum cephalosporins in Klebsiella pneumoniae, Escherichia coli, and Proteus mirabilis isolates recovered in South Africa. Antimicrobial Agents and Chemotherapy. 42, 1350-1354. DOI: 10.1128/AAC.42.6.1350

Poeta, P., Costa, D., Rodrigues, J. and Torres, C. (2005). Study of faecal colonization by vanA-containing Enterococcus strains in healthy humans, pets, poultry and wild animals in Portugal. Journal of Antimicrobial Chemotherapy. 55,278-280. DOI: 10.1093/jac/dkh549

Saenz ,Y., Brinas, L., Domínguez, E., Ruiz, J., Zarazaga, M., Vila, J. and Torres. C. (2004). Mechanisms of resistance in multiple-antibiotic-resistant Escherichia coli strains of human, animal, and food origins. Antimicrobial Agents and Chemotherapy. 48, 3996-4001. DOI: 10.1128/AAC.48.10.39964001.2004

Seguin, M.A., Vaden A.C., Stone, E. and Levine, J.F. (2003). Persistent urinary tract infections and reinfections in 100 dogs (1989-1999). Journal of Veterinary Internal Medicine. 17, 622-631. DOI: 10.1111/j.19 39-1676.2003.tb02492.x

Rweyemamu, M., Chakraborty, T., Mshana, S.E. (2016). Multiple ESBL-Producing Escherichia coli Sequence Types Carrying Quinolone and Aminoglycoside Resistance Genes Circulating in Companion and Domestic Farm Animals in Mwanza, Tanzania, Harbor Commonly Occurring Plasmids, Frontiers in Microbiology, 11, 142. DOI: 10.3389/fmicb.2016.00142

Simjee, S., White, D.G., McDermott, P.F., Wagner, D.D., Zervos, M.J., Donabedian, S.M., English, L.L., Hayes, J.R. and Walker, R.D. (2002).
Characterization of Tn1546 in vancomycin-resistant Enterococcus faecium isolated from canine urinary tract infections: evidence of gene exchange between human and animal enterococci. Journal of Clinical Microbiology. 40, 4659-4665. DOI: 10.1128/JCM.40.12.4659-4665.2002

Sodha, S.V., Lynch, M., Wannemuehler, K., Leeper, M., Malavet, M., Schaffzin, J., Chen, T., Langer, A., Glenshaw, M., Hoefer, D. and Dumas, N. (2011). Multistate outbreak of Escherichia coli O157: H7 infections associated with a national fast-food chain, 2006: a study incorporating epidemiological and food source traceback results. Epidemiology and Infection, 139,309-316. DOI: 10.1017/S095026881 0000920

Sørum, H. and Sunde. M. (2001). Resistance to antibiotics in the normal flora of animals. Veterinary Research, 32, 227-241. DOI: 10.1051/vetres:2001121

Sow, A.G., Wane, A.A., Diallo, M.H., Boye, C.S.B. and Aïdara-Kane, A. (2007). Genotypic characterization of antibiotic-resistant Salmonella enteritidis isolates in Dakar, Senegal. Journal of Infection in Developing Countries, 1,284-288. PMID: 19734606

Stokholm, J., Schjørring, S., Pedersen, L., Bischoff, A.L., Følsgaard, N., Carson, C.G., Chawes, B., Bønnelykke, K., Mølgaard, A., Krogfelt, K.A. and Bisgaard, H. (2012). Living with cat and dog increases vaginal colonization with $E$. coli in pregnant women. PLoS One. 7, 1-7. DOI.org/10.1371/journal.pone.0046226

Rubab, M. and Oh, D. H. (2021). Molecular Detection of Antibiotic Resistance Genes in Shiga ToxinProducing E. coli Isolated from Different Sources. Antibiotics, $10(4), \quad 344$. DOI.org/10.3390/antibiotics10040344

Tramuta, C., Robino, P., Nucera, D., Salvarani, S., Banche, G., Malabaila, A. and Nebbia, P. (2014). Molecular characterization and antimicrobial resistance of faecal and urinary Escherichia coli isolated from dogs and humans in Italy. Veterinary Italia, 50,2330. DOI: 10.12834/VetIt.1304.09

Vo, A.T., van Duijkeren, E., Fluit, A.C. and Gaastra, W. (2007). Characteristics of extended-spectrum cephalosporin-resistant Escherichia coli and Klebsiella pneumoniae Isolates from horses. Veterinary Microbiology, 124, 248-255. DOI: 10.1016/j.vetmic.2007.04.027

Von Baum, H. and Marre, R. (2005). Antimicrobial resistance of Escherichia coli and therapeutic implications. International Journal of Medical Microbiology, 295,503511. DOI: 10.1016/j.ijmm.2 005.07.002

Windahl, U., Holst, B.S., Nyman, A., Grönlund, U .and Bengtsson, B. (2014). Characterisation of bacterial growth and antimicrobial susceptibility patterns in canine urinary tract infections. BMC Veterinary. Research. 10, 217. DOI: 10.1186/s12917-0140217-4 